(c) American Dairy Science Association, 2007.

\title{
Effects of Dietary Cation-Anion Difference and Potassium to Sodium Ratio on Lactating Dairy Cows in Hot Weather
}

\author{
C. D. Wildman, J. W. West, ${ }^{1}$ and J. K. Bernard \\ Department of Animal and Dairy Science, The University of Georgia, Tifton 31793-0748
}

\begin{abstract}
Forty-two lactating Holstein cows $188 \pm 59 \mathrm{~d}$ in milk were used in an 8-wk randomized complete block trial with a $2 \times 3$ factorial arrangement of treatments. The objective was to determine the effects of high dietary cation-anion difference (DCAD) and K:Na ratio on milk yield and composition and blood acid-base chemistry. Treatments included DCAD concentrations of 45 or 60 $\mathrm{mEq}(\mathrm{Na}+\mathrm{K}-\mathrm{Cl}) / 100 \mathrm{~g}$ of feed dry matter and $\mathrm{K}: \mathrm{Na}$ ratios of $2: 1,3: 1$, or $4: 1$. Mean DCAD values were later determined to be 41 and 58. Dry matter intake was similar across treatments. Yield of milk and energy corrected milk were lower for the $3: 1 \mathrm{~K}: \mathrm{Na}$ ratio compared with 2:1 and 4:1 ratios. Blood urea $\mathrm{N}$ was lower for the highest DCAD, suggesting that DCAD possibly reduced protein degradation or altered protein metabolism and retention. Mean temperature-humidity index was 75.6 for the duration of the trial, exceeding the critical value of 72 for all weeks during the treatment period. Cows maintained relatively normal body temperature with mean a.m. and p.m. body temperature of 38.5 and $38.7^{\circ} \mathrm{C}$, respectively. These body temperatures suggest that cows were not subject to extreme heat stress due to good environmental control. Results of this trial indicate that the greatest effect on milk yield occurs when either $\mathrm{Na}$ or $\mathrm{K}$ is primarily used to increase DCAD, with the lowest yield of energy-corrected milk at a $3: 1 \mathrm{~K}: \mathrm{Na}$ ratio $(27.1 \mathrm{~kg} / \mathrm{d})$ compared with ratios of $2: 1(29.3 \mathrm{~kg} / \mathrm{d})$ and $4: 1(28.7 \mathrm{~kg} / \mathrm{d})$. Results also suggest that greater DCAD improves ruminal N metabolism or $\mathrm{N}$ utilization may be more efficient with a high DCAD. Key words: dietary cation-anion difference, sodium, potassium, blood urea nitrogen
\end{abstract}

\section{INTRODUCTION}

The effect of DCAD on animal physiology and production has been investigated in several species including dairy cows, swine, and beef steers (Block, 1994; Ross

Received June 21, 2006.

Accepted October 13, 2006.

${ }^{1}$ Corresponding author: joewest@uga.edu et al., 1994; Patience and Chaplin, 1997). The DCAD, defined as $\mathrm{mEq}(\mathrm{Na}+\mathrm{K}-\mathrm{Cl}) / 100 \mathrm{~g}$ of feed $\mathrm{DM}$, is a method by which the acid-base chemistry of the cow can be altered by manipulating the amount of $\mathrm{Na}, \mathrm{K}$, or $\mathrm{Cl}$ included in the diet. Although considerable DCAD research has focused on the periparturient dairy cow and the reduction of incidence of milk fever (Block, 1984; Oetzel et al., 1988), the impact of DCAD on the lactating cow has also been studied. West et al. (1991) reported a linear increase in milk yield (MY) and a quadratic increase in DMI when cows were fed diets ranging in DCAD from -7.9 to $32.4 \mathrm{mEq} / 100 \mathrm{~g}$ of DM. Tucker et al. (1988b) reported higher DMI and MY in cows fed diets with DCAD level of $+20 \mathrm{mEq} / 100 \mathrm{~g}$ of DM compared with those fed a DCAD level of $-10 \mathrm{mEq} /$ $100 \mathrm{~g}$ of DM. Meta-analyses (Hu and Murphy, 2004) of multiple macromineral studies indicated that DMI peaked at a DCAD of $40 \mathrm{mEq} / 100 \mathrm{~g}$ of DM, and MY was maximized at $34 \mathrm{mEq} / 100 \mathrm{~g}$ of DM. Sanchez and Beede (1996) reported that DMI and MY were maximized at $38 \mathrm{mEq} / 100 \mathrm{~g}$ of feed $\mathrm{DM}$ and that the optimal range for DCAD was between 25 and $50 \mathrm{mEq} / 100 \mathrm{~g}$ of DM based on a similar analysis.

Results of previous research differ concerning the role of ion source in the formulation of lactating dairy cow rations. No differences in DMI or MY were observed when either $\mathrm{Na}$ or $\mathrm{K}$ was used as the cation source (West et al., 1992). Tucker et al. (1988a) also concluded that DCAD is more important than the individual ions used to alter the DCAD in lactating cows. These studies determined the effect of cation source; there is little information regarding the effect of varying ratios of dietary $\mathrm{K}$ to $\mathrm{Na}$ in lactating cow rations. Sanchez et al. (1997) compared dietary proportions of $\mathrm{NaHCO}_{3}, \mathrm{NaCl}$, and $\mathrm{KCl}$ and observed that DMI was influenced by an interaction between $\mathrm{Na}$ and $\mathrm{K}$ and between $\mathrm{Na}$ and $\mathrm{Cl}$. The authors also observed increased 3.5\% FCM with higher dietary $\mathrm{Na}$ and concluded that interrelationships exist among Na, K, and Cl. Sanchez et al. (1994) reported that the DMI and MY response to one cation ( $\mathrm{Na}$ or $\mathrm{K}$ ) tends to be the greatest when the dietary level of the other cation is low. The objective of the present study was to determine the effects of adjusting $\mathrm{K}: \mathrm{Na}$ ratios within high DCAD concentrations on DMI, MY, and serum and urinary electrolyte concentrations. 
Table 1. Ingredient composition of diets containing a DCAD of 41 or $58 \mathrm{mEq} \mathrm{Na}+\mathrm{K}-\mathrm{Cl} / 100 \mathrm{~g}$ of DM and $\mathrm{K}: \mathrm{Na}$ ratio of $2: 1,3: 1$, or $4: 1$

\begin{tabular}{|c|c|c|c|c|c|c|}
\hline \multirow[b]{3}{*}{ Ingredient } & \multicolumn{6}{|c|}{ DCAD and $\mathrm{K}: \mathrm{Na}$ ratio } \\
\hline & \multicolumn{3}{|c|}{41} & \multicolumn{3}{|c|}{58} \\
\hline & $2: 1$ & $3: 1$ & $4: 1$ & $2: 1$ & $3: 1$ & $4: 1$ \\
\hline & \multicolumn{6}{|c|}{$-\%$ of $\mathrm{DM}$} \\
\hline Corn silage & 51.58 & 51.58 & 51.58 & 51.58 & 51.58 & 51.58 \\
\hline Cottonseed hulls & 7.22 & 7.22 & 7.22 & 7.22 & 7.22 & 7.22 \\
\hline Ground corn & 17.37 & 17.37 & 17.37 & 17.37 & 17.37 & 17.37 \\
\hline Base concentrate ${ }^{1}$ & 16.92 & 16.92 & 16.92 & 16.92 & 16.92 & 16.92 \\
\hline Mineral premix ${ }^{2}$ & 2.07 & 2.07 & 2.07 & 2.07 & 2.07 & 2.07 \\
\hline Ground corn ${ }^{3}$ & 2.48 & 2.50 & 2.58 & 1.22 & 1.36 & 1.44 \\
\hline $\mathrm{NaHCO}_{3}{ }^{3}$ & 1.82 & 1.20 & 0.83 & 2.41 & 1.61 & 1.16 \\
\hline $\mathrm{K}_{2} \mathrm{CO}_{3}{ }^{3}$ & 0.02 & 0.58 & 0.87 & 0.63 & 1.29 & 1.66 \\
\hline $\mathrm{MgSO}_{4}{ }^{3}$ & 0.52 & 0.56 & 0.56 & 0.58 & 0.58 & 0.58 \\
\hline
\end{tabular}

${ }^{1}$ Base concentrate contained $78.79 \%$ soybean meal, $14.55 \%$ ProLak (H.J. Baker \& Bro., Inc., Westport, CT), 3.64\% Megalac Plus (Church \& Dwight Co., Inc., Princeton, NJ), 2.42\% Megalac (Church \& Dwight Co., Inc.), and $0.60 \%$ urea (DM basis).

${ }^{2}$ Mineral premix contained $64.58 \%$ limestone, $10.42 \%$ salt, $10.42 \%$ distillers grain, $8.33 \%$ magnesium oxide, and $6.25 \%$ vitamin-trace mineral premix.

${ }^{3}$ These ingredients were mixed in a treatment premix for inclusion in each respective diet.

\section{MATERIALS AND METHODS}

\section{Experimental Design}

Forty-two multiparous Holstein cows averaging 188 \pm 59 DIM were used in a randomized complete block design with a $2 \times 3$ factorial arrangement of treatments. The trial was conducted from May 23 to July 31 and consisted of a 2-wk standardization period (SP) followed by an 8-wk treatment period (TP). During the SP cows were offered the standard herd diet, and baseline measures were taken for DMI, MY, BW, milk composition, and serum and urinary electrolyte concentrations. Data collected during the SP were used for covariate analysis of TP data. Cows were ranked by DMI per BW $(\mathrm{kg} / 100 \mathrm{~kg})$ during the SP, blocked into groups of 6 by rank, and then assigned randomly to treatment within block.

Experimental diets contained 51.6\% corn silage and $48.4 \%$ concentrate (dry basis) formulated to meet minimum NRC (2001) requirements (Table 1). Dietary treatments were formulated for DCAD of 45 (LD) or 60 (HD) $\mathrm{mEq}(\mathrm{Na}+\mathrm{K}-\mathrm{Cl}) / 100 \mathrm{~g}$ of $\mathrm{DM}$, and $\mathrm{K}: \mathrm{Na}$ ratio of $2: 1$ (KNa2), 3:1 (KNa3), or 4:1 (KNa4) within each DCAD treatment. The DCAD and $\mathrm{K}: \mathrm{Na}$ ratios were adjusted using $\mathrm{NaHCO}_{3}$ as a $\mathrm{Na}$ source and $\mathrm{K}_{2} \mathrm{CO}_{3}$ as a $\mathrm{K}$ source and were added to experimental premixes using ground corn as a carrier. Actual DCAD values were lower than originally formulated (Table 2). Mean DCAD for the 3 $\mathrm{LD}$ treatment combinations was $41 \mathrm{mEq} / 100 \mathrm{~g}$ of DM compared with $58 \mathrm{mEq} / 100 \mathrm{~g}$ of DM for the $3 \mathrm{HD}$ treatment combinations. Although DCAD was slightly lower than formulated, the difference between the 2 treatments was larger than originally formulated, preserv- ing the DCAD treatment difference. Calculation of the 4-element DCAD equation, defined as $\mathrm{mEq}(\mathrm{Na}+\mathrm{K})-$ $(\mathrm{Cl}+\mathrm{S}) / 100 \mathrm{~g}$ of DM, is also included in Table 2 .

Before the start of the SP, cows were trained to operate electronic gate feeders (American Calan, Inc., Northwood, NH). Cows were fed experimental diets once daily ( $0800 \mathrm{~h})$ as a TMR, with the amount of feed offered recorded and adjusted daily based on the previous day's consumption to allow $10 \%$ orts. The TMR was pushed up at least 4 times daily. Feed DM content for adjustment of ration components was determined weekly by drying at $60^{\circ} \mathrm{C}$ for $72 \mathrm{~h}$ in a forced air oven. Cows were housed in a freestall barn with fans activated by thermostat when the ambient temperature exceeded $24^{\circ} \mathrm{C}$. Cows were milked twice daily at approximately 0400 and $1500 \mathrm{~h}$.

\section{Sampling}

Forage, concentrate, treatment mixes, and TMR were sampled 3 times weekly, dried at $60^{\circ} \mathrm{C}$ for $72 \mathrm{~h}$, and composited by week for analysis. Samples were ground to pass through a 1-mm screen using a Wiley mill (Arthur H. Thomas Co., Philadelphia, PA). Feed N was determined using a Kjeltec System (Foss Tecator AB, Höganäs, Sweden) and CP was calculated as the percentage $\mathrm{N} \times 6.25$ (AOAC, 1990). Acid detergent fiber and NDF were determined according to the method of Van Soest et al. (1991). Samples were extracted with nitric and acetic acids for determination of chloride concentration using a chloridometer (Haake Buchler Instruments, Inc., Saddle Brook, NJ) as outlined by Cotlove et al. (1958). Phosphorus concentration was deter- 
Table 2. Chemical composition ${ }^{1}$ of diets containing a DCAD of 41 or $58 \mathrm{mEq}(\mathrm{Na}+\mathrm{K}-\mathrm{Cl}) / 100 \mathrm{~g}$ of $\mathrm{DM}$ and $\mathrm{K}: \mathrm{Na}$ ratio of $2: 1,3: 1$, or $4: 1$

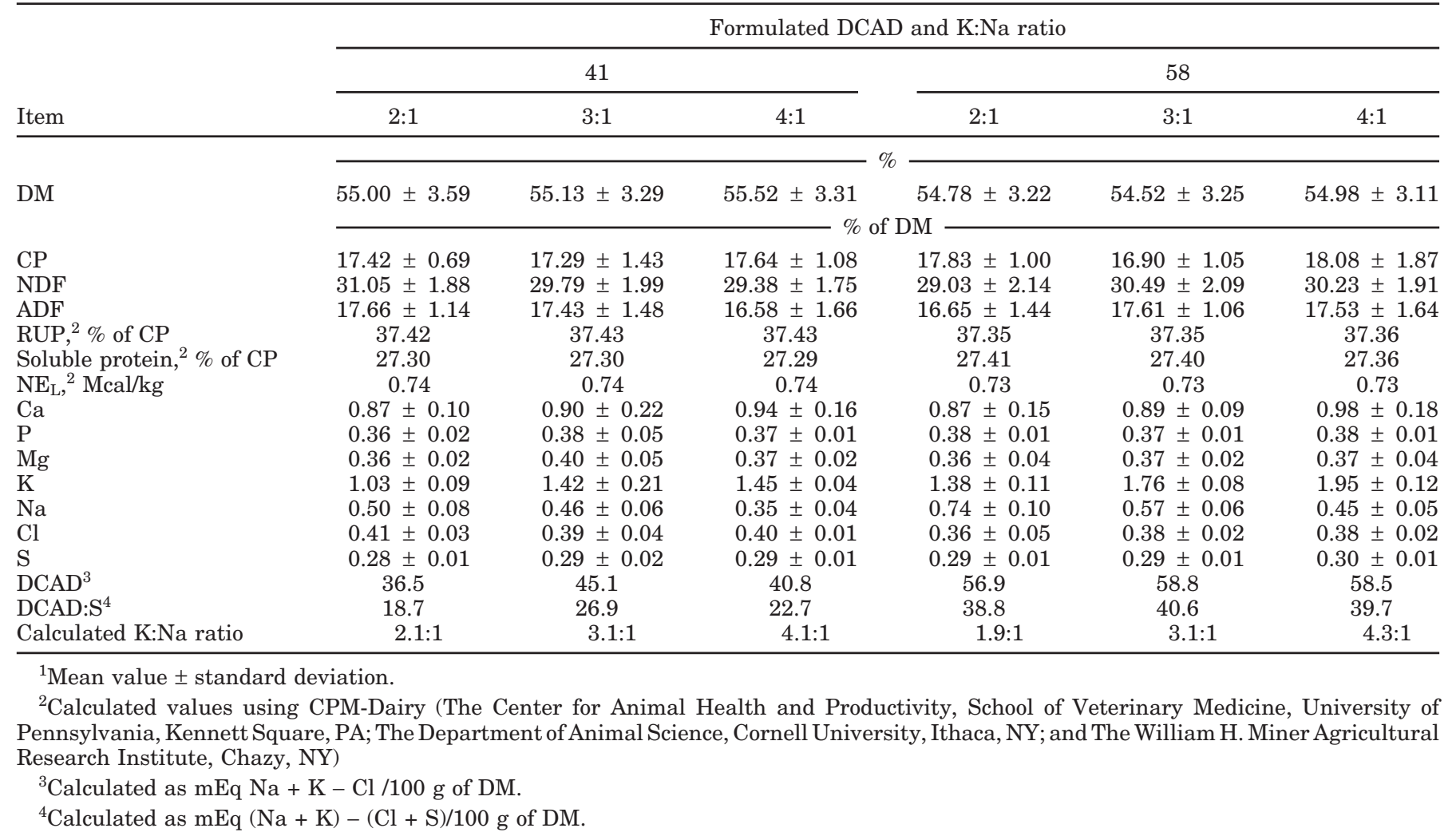

mined by colorimetry (Beckman DU Series 500 spectrophotometer, Beckman Instruments, Inc., Fullerton, CA) following wet ashing (AOAC, 1990). Other minerals were measured by atomic absorption spectrophotometry (model no. 3030, Perkin-Elmer, Norwalk, CT) following wet ashing (AOAC, 1990).

Milk yield was measured using electronic meters (DeLaval, Kansas City, MO). Milk samples were collected weekly from consecutive p.m. and a.m. milkings throughout the trial. Samples were shipped to Southeast Milk Inc. (Belleview, FL) for analyses of fat and protein using infrared analysis (B2000, Bentley Instruments Inc., Chaska, MN).

Blood was collected by jugular venipuncture into evacuated tubes at approximately $1300 \mathrm{~h}$ at the end of the SP and 3 times during the TP. Samples were centrifuged at $2,500 \times g$ for $20 \mathrm{~min}$ for separation of serum. Serum was harvested and analyzed immediately for $\mathrm{Ca}, \mathrm{P}, \mathrm{Mg}, \mathrm{Na}, \mathrm{K}, \mathrm{Cl}$, bicarbonate, BUN, creatinine, and glucose using a Boehringer Mannheim/Hitachi 912 automated chemistry analyzer (Roche Laboratory Systems, Indianapolis, IN) at the University of Georgia Veterinary Diagnostic Laboratory in Tifton. Urine samples were collected via manual stimulation at the same time as blood collection for analysis of the same components as for blood serum for determination of fractional excretion. Fractional excretion was calculated as ([urinary mineral]/[plasma mineral]) $\times$ ([plasma creatinine]/[urinary creatinine] $) \times 100$ (Vander, 1991). Respiratory rates were recorded at 1300 $\mathrm{h}$ once during the SP and 3 times during the TP. Respiration rate was determined for each cow for $1 \mathrm{~min}$ by 2 individuals. Counts exceeding 10\% error were recounted until a difference of less than $10 \%$ was obtained.

Milk temperature has been highly correlated with deep body temperature (Bitman et al., 1982) and rectal temperature (Igono et al., 1985, 1987) due to the large volume of blood entering the mammary gland. Milk temperature was measured at each milking using a thermocouple in one short milk tube of each milker (Temp-Sense, Udder Health Systems, Bellingham, WA). Ambient temperature and relative humidity $(\mathbf{R H})$ were recorded hourly at 3 locations in the freestalls and feeding area using a HOBO Pro RH/Temp Data Logger (Onset Computer Corp., Bourne, MA). Mean values across locations were used for analysis. Temperaturehumidity index (THI) was calculated as THI $=\mathrm{db}-$ $(0.55-0.55 \times \mathrm{RH}) \times(\mathrm{db}-58)$, where $\mathrm{db}$ was the dry bulb temperature in degrees Fahrenheit and $\mathrm{RH}$ was expressed in decimals (NOAA, 1976). 
Table 3. Environmental conditions for the trial

\begin{tabular}{lccccccccccc}
\hline & \multicolumn{10}{c}{ Week $^{1}$} \\
\cline { 2 - 12 } Item & 1 & 2 & 3 & 4 & 5 & 6 & 7 & 8 & 9 & 10 & Mean $\pm \mathrm{SD}$ \\
\hline Maximum temperature, ${ }^{\circ} \mathrm{C}$ & 30.4 & 31.1 & 29.1 & 31.2 & 31.0 & 31.5 & 33.4 & 31.3 & 30.4 & 30.8 & $31.0 \pm 1.0$ \\
Minimum temperature, $^{\circ} \mathrm{C}$ & 18.8 & 21.7 & 22.5 & 22.2 & 21.8 & 22.5 & 23.7 & 22.0 & 22.2 & 22.9 & $22.0 \pm 1.2$ \\
Maximum RH, $^{2} \%$ & 90.4 & 96.1 & 97.6 & 94.0 & 93.4 & 93.9 & 93.7 & 94.3 & 95.2 & 96.5 & $94.5 \pm 1.9$ \\
Minimum RH, \% $^{\text {Maximum THI }}{ }^{3}$ & 51.0 & 52.7 & 67.9 & 59.6 & 53.7 & 60.7 & 55.9 & 48.2 & 58.5 & 63.2 & $57.1 \pm 5.7$ \\
Minimum THI $_{\text {Mean THI }}^{79.0}$ & 79.9 & 79.5 & 81.4 & 80.1 & 82.0 & 83.9 & 80.2 & 80.1 & 81.8 & $80.8 \pm 1.4$ \\
Thy & 63.2 & 69.8 & 71.6 & 70.1 & 69.2 & 70.6 & 72.6 & 71.1 & 71.5 & 72.9 & $70.3 \pm 2.6$ \\
\hline
\end{tabular}

${ }^{1} \mathrm{Wk} 1$ and 2 were the standardization period; wk 3 through 10 were the treatment period.

${ }^{2} \mathrm{RH}=$ Relative humidity.

${ }^{3} \mathrm{THI}=$ Temperature-humidity index $={ }^{\circ} \mathrm{F}-(0.55-0.55 \times \mathrm{RH}) \times\left({ }^{\circ} \mathrm{F}-58\right) ;$ NOAA, 1976 .

\section{Statistical Analysis}

Data were analyzed as a randomized complete block design with a factorial arrangement of treatments using the PROC MIXED procedure of SAS (SAS Institute, 1999). Cow within treatment was included as the random variable, with week as the repeated measure. The model was as follows:

$$
\begin{aligned}
\mathrm{Y}_{\mathrm{ijklm}}= & \mu+\mathrm{I}+\mathrm{B}_{\mathrm{i}}+\mathrm{D}_{\mathrm{j}}+\mathrm{R}_{\mathrm{k}}+\mathrm{DR}_{\mathrm{jk}}+\mathrm{W}_{\mathrm{l}}+\mathrm{DW}_{\mathrm{jl}} \\
& +\mathrm{RW}_{\mathrm{kl}}+\mathrm{DRW}_{\mathrm{jkl}}+\mathrm{C}_{\mathrm{m}(\mathrm{ijk})}+\mathrm{e}_{\mathrm{ijk} \mathrm{k} m}
\end{aligned}
$$

where $\mu=$ the mean intercept, $I=$ the covariate, $B_{i}=$ the effect due to the ith block, $D_{j}=$ the effect due to the jth $\mathrm{DCAD}, \mathrm{R}_{\mathrm{k}}=$ the effect due to the kth $\mathrm{K}: \mathrm{Na}$ ratio, $\mathrm{W}_{\mathrm{l}}=$ the effect due to the lth week, $\mathrm{C}_{\mathrm{m}(\mathrm{ijk})}=$ the effect due to cow $m$ being in the ith block with the jth DCAD and kth $\mathrm{K}: \mathrm{Na}$ ratio, and $\mathrm{e}_{\mathrm{ijklm}}=$ residual error associated with each $\mathrm{Y}_{\mathrm{ijklm}}$.

Least squares means with a significant $F$-test $(P<$ $0.10)$ were compared using PDIFF of SAS. Linear and quadratic orthogonal contrasts were included in the model to determine the effect of $\mathrm{K}: \mathrm{Na}$ ratio.

\section{RESULTS AND DISCUSSION}

\section{Environmental Conditions}

Environmental conditions during the study are presented in Table 3. Mean maximum and minimum daily temperature averaged 31.0 to $22.0^{\circ} \mathrm{C}$ and were similar throughout the trial. Holstein cows become less productive due to heat stress when daily mean THI exceeds 72 (Johnson, 1987). The mean daily THI during this trial was 75.6 , which greatly exceeded this critical value. Except for wk 1 of the SP, the mean weekly THI exceeded 72 for the duration of the trial (Table 3).

\section{DMI}

The DMI was similar for all treatments (Table 4). Early DCAD work by Tucker et al. (1988a) reported an
$11 \%$ increase in DMI when DCAD was increased from -10 to $+20 \mathrm{mEq} / 100 \mathrm{~g}$ of $\mathrm{DM}$, although these DCAD concentrations were considerably lower than those used in the present study and are lower than the DCAD resulting from current NRC (2001) recommendations $(27 \mathrm{mEq} / 100 \mathrm{~g}$ of $\mathrm{DM})$ for $\mathrm{Na}, \mathrm{K}$, and $\mathrm{Cl}(0.19,1.02$, and $0.25 \%$, respectively). West et al. (1991) observed a quadratic response for DMI when DCAD increased from -7.94 to $32.4 \mathrm{mEq} / 100 \mathrm{~g}$ of $\mathrm{DM}$ during cool weather and -11.7 to $31.2 \mathrm{mEq} / 100 \mathrm{~g}$ of DM during hot weather. The authors reported that DMI plateaued at a DCAD of approximately $20 \mathrm{mEq} / 100 \mathrm{~g}$ of $\mathrm{DM}$, suggesting a limit in DMI response to DCAD with mineral concentrations above NRC (2001) recommendations for $\mathrm{Na}, \mathrm{K}$, and $\mathrm{Cl}$. In later work, however, West et al. (1992) reported a positive linear response for DMI as DCAD was increased from 12 to $46 \mathrm{mEq} / 100 \mathrm{~g}$ of DM. Sanchez and Beede (1996) reported that DMI was maximized when DCAD ranged from 25 to $50 \mathrm{mEq} / 100 \mathrm{~g}$ of DM. In a similar analysis of data from 17 published studies, $\mathrm{Hu}$ and Murphy (2004) reported that DMI was maximal at a DCAD of $40 \mathrm{mEq} / 100 \mathrm{~g}$ of DM. In both reports, a curvilinear relationship was observed; DMI declined when DCAD concentrations were outside the optimal range. The absence of an effect of DCAD on DMI in the present study suggests that at ranges as narrow as 15 $\mathrm{mEq} / 100 \mathrm{~g}$ of DM, the homeostatic controls handle the excess cations in the system via urinary excretion without decreasing DMI, as is reflected by greater urinary $\mathrm{K}$ excretion for HD. These data also suggest that the lowest DCAD was adequate for conditions in the present study.

The lack of response to $\mathrm{K}: \mathrm{Na}$ is consistent with the results of Tucker et al. (1988a, 1991) and West et al. (1992) who reported that DCAD was more important than the ion used to alter DCAD in lactating cows. The reduction in DMI reported by Schneider et al. (1984) when $\mathrm{KHCO}_{3}$ was used instead of $\mathrm{NaHCO}_{3}$ as a cation source may have been caused by poor palatability from a relatively dry ration. Corn silage used in the present 
Table 4. Dry matter intake, milk and milk component yield, and milk composition for cows fed diets containing a DCAD of 41 or $58 \mathrm{mEq}(\mathrm{Na}+\mathrm{K}-\mathrm{Cl}) / 100 \mathrm{~g}$ of $\mathrm{DM}$ and $\mathrm{K}: \mathrm{Na}$ ratio of $2: 1,3: 1$, or $4: 1$

\begin{tabular}{|c|c|c|c|c|c|c|c|c|c|c|}
\hline \multirow[b]{3}{*}{ Item } & \multicolumn{6}{|c|}{ DCAD and $\mathrm{K}: \mathrm{Na}$ ratio } & \multirow[b]{3}{*}{ SEM } & \multirow{2}{*}{\multicolumn{3}{|c|}{$P$}} \\
\hline & \multicolumn{3}{|c|}{41} & \multicolumn{3}{|c|}{58} & & & & \\
\hline & $2: 1$ & $3: 1$ & $4: 1$ & $2: 1$ & $3: 1$ & $4: 1$ & & DCAD & Ratio & $\mathrm{DCAD} \times$ Ratio \\
\hline \multicolumn{11}{|l|}{ DMI } \\
\hline $\mathrm{kg} / \mathrm{d}$ & 22.4 & 22.3 & 23.8 & 23.0 & 23.5 & 22.2 & 0.94 & $\mathrm{NS}^{1}$ & NS & NS \\
\hline $\mathrm{kg} / 100 \mathrm{~kg}$ of BW & 3.84 & 3.82 & 3.92 & 3.73 & 3.66 & 4.07 & 0.17 & NS & NS & NS \\
\hline \multicolumn{11}{|l|}{ Yield, kg/d } \\
\hline Milk & 27.5 & 26.1 & 28.8 & 27.9 & 26.4 & 27.4 & 0.87 & NS & $\mathrm{Q}^{2}$ & NS \\
\hline $\mathrm{ECM}^{3}$ & 28.8 & 26.4 & 29.7 & 29.8 & 27.7 & 27.6 & 1.04 & NS & $\mathrm{Q}$ & NS \\
\hline Fat & 1.07 & 0.98 & 1.11 & 1.12 & 1.07 & 1.03 & 0.06 & NS & NS & NS \\
\hline Protein & 0.83 & 0.79 & 0.86 & 0.83 & 0.81 & 0.80 & 0.03 & NS & NS & NS \\
\hline \multicolumn{11}{|l|}{ Composition, \% } \\
\hline Fat & 3.85 & 3.82 & 3.90 & 3.91 & 3.84 & 3.92 & 0.08 & NS & NS & NS \\
\hline Protein & 3.03 & 3.16 & 3.01 & 3.02 & 3.08 & 2.95 & 0.06 & NS & $\mathrm{Q}$ & NS \\
\hline
\end{tabular}

study may have masked flavors and minimized palatability problems. Although DMI was similar across $\mathrm{K}: \mathrm{Na}$ ratio, there was a trend $(P=0.12)$ for increased $\mathrm{DMI} / 100 \mathrm{~kg}$ of $\mathrm{BW}$ for $\mathrm{KNa} 4$. However, initial BW for these cows was numerically lower than for other treatments (Table 4) and may have contributed to greater $\mathrm{DMI} / 100 \mathrm{~kg}$ of $\mathrm{BW}$.

\section{MY and Milk Composition}

Milk yield and composition were similar for both DCAD (Table 4), which is consistent with results for DMI. Previous research reporting greater MY with higher DCAD (Tucker et al., 1988a; West et al., 1991) indicated the greatest MY response at DCAD levels lower than those used in the present study. Because the objective of this trial was to determine the effect of altering $\mathrm{K}: \mathrm{Na}$ ratio at high $\mathrm{DCAD}$ concentrations, and a quadratic relationship $(P<0.05)$ exists for MY and DCAD (Sanchez and Beede, 1996; Hu and Murphy, 2004), potential exists for depressed MY and DMI when DCAD exceeds the previously reported optimal range (Sanchez and Beede, 1994, 1996; Hu and Murphy, 2004). The absence of a DCAD response for DMI and MY suggests that at high DCAD, a $15 \mathrm{mEq} / 100 \mathrm{~g}$ of DM difference in DCAD concentration is not sufficient to depress DMI or MY.

A quadratic K:Na effect for MY $(P=0.03)$ and ECM $(P=0.04)$ was observed (Table 4$)$. Mean MY decreased from $27.7 \mathrm{~kg} / \mathrm{d}$ for $\mathrm{KNa} 2$ to $26.2 \mathrm{~kg} / \mathrm{d}$ for $\mathrm{KNa} 3$. An increase was then observed to $28.1 \mathrm{~kg} / \mathrm{d}$ for $\mathrm{KNa} 4$. A similar relationship was observed for ECM with mean yields of $29.3,27.1$, and $28.7 \mathrm{~kg} / \mathrm{d}$ for $\mathrm{KNa} 2, \mathrm{KNa} 3$, and $\mathrm{KNa} 4$, respectively. These results are consistent with previous research in which interactions were observed for $\mathrm{Na}$ and K. Sanchez et al. (1994) reported the greatest response in milk yield to either high $\mathrm{Na}$ or $\mathrm{K}$ when the concentration of the other ion was low. Erdman et al. (1980) and O'Connor et al. (1988), however, reported no effect of additional $\mathrm{Na}$ when fed with low, adequate, or high $\mathrm{K}$.

A quadratic $\mathrm{K}: \mathrm{Na}$ ratio effect was observed for milk protein percentage $(P=0.04)$ across DCAD with mean values of $3.02,3.12$, and $2.98 \%$ for $\mathrm{KNa} 2, \mathrm{KNa} 3$, and $\mathrm{KNa} 4$, respectively. This response is inversely related to that noted for MY and is most likely a dilution effect because milk protein yield was similar among treatments. No differences were noted among K:Na ratios for milk fat percentage or milk fat yield. Although not statistically different, milk fat yield was numerically lower for $\mathrm{KNa} 3$ within $\mathrm{LD}$ treatments. Further research with a larger number of cows might allow for the detection of a statistical difference in fat yield based on $\mathrm{K}: \mathrm{Na}$ ratio.

\section{$B W$ and Temperature}

No differences in initial BW or BW gain were observed for DCAD or K:Na ratio treatments (Table 5). No significant $\mathrm{DCAD} \times \mathrm{K}: \mathrm{Na}$ ratio interactions were observed for a.m. milk temperature, p.m. milk temperature, or temperature difference (Table 5). However, a.m. milk temperature declined linearly $(P<0.05)$ with greater K:Na ratios. The difference in a.m. to p.m. temperature increased linearly $(P<0.10)$ as $\mathrm{K}: \mathrm{Na}$ ratio increased, with the largest change observed in $\mathrm{KNa} 4$ (Table 5). West et al. (1992) observed decreased a.m. and p.m. milk temperature for cation sources added to the diet that was attributed to disparity in BW among treatment groups. This is consistent with the trend for 
Table 5. Mean BW, respiration rate, and milk temperature for cows fed diets containing a DCAD of 41 or $58 \mathrm{mEq}(\mathrm{Na}+\mathrm{K}-\mathrm{Cl}) / 100 \mathrm{~g}$ of DM and K:Na ratio of $2: 1,3: 1$, or $4: 1$

\begin{tabular}{|c|c|c|c|c|c|c|c|c|c|c|}
\hline \multirow[b]{3}{*}{ Item } & \multicolumn{6}{|c|}{ DCAD and $\mathrm{K}: \mathrm{Na}$ ratio } & \multirow[b]{3}{*}{ SEM } & \multirow{2}{*}{\multicolumn{3}{|c|}{$P$}} \\
\hline & \multicolumn{3}{|c|}{41} & \multicolumn{3}{|c|}{58} & & & & \\
\hline & $2: 1$ & $3: 1$ & $4: 1$ & $2: 1$ & $3: 1$ & $4: 1$ & & DCAD & Ratio & $\mathrm{DCAD} \times$ Ratio \\
\hline Initial BW, kg & 587.5 & 597.9 & 609.5 & 623.6 & 662.3 & 548.5 & 29.9 & $\mathrm{NS}^{1}$ & NS & NS \\
\hline BW change, $\mathrm{kg}$ & 8.1 & 4.5 & 1.1 & -1.2 & 6.0 & 1.4 & 3.6 & NS & NS & NS \\
\hline Respiration rate, breaths/min & 81 & 83 & 77 & 83 & 73 & 82 & 4 & NS & NS & NS \\
\hline
\end{tabular}

${ }^{1} \mathrm{NS}=$ Not significant $(P>0.10)$.

${ }^{2}$ Calculated as (p.m. temperature - a.m. temperature).

${ }^{3} \mathrm{~L}=$ Linear effect.

$* P<0.05 ; \dagger P<0.10$.

a linear K:Na effect for a.m. to p.m. temperature change observed in the present study. Within the HD treatment, the greatest a.m. to p.m. temperature change occurred for lighter BW cows. The ability of lower BW animals to dissipate heat would improve body heat loss. Although respiratory rates were elevated across treatments due to heat stress, no differences were observed between DCAD or among $\mathrm{K}: \mathrm{Na}$ ratio for respiratory rate (Table 5). Cows maintained relatively normal body temperatures $\left(38.5^{\circ} \mathrm{C}\right.$ a.m. temperature and $38.7^{\circ} \mathrm{C}$ p.m. temperature) and were not subject to severe heat stress due to good environmental control with highvelocity fans.

\section{Blood and Urinary Metabolites}

No differences were noted for serum $\mathrm{Ca}, \mathrm{Na}, \mathrm{Cl}$, or bicarbonate concentration (Table 6). Increased serum bicarbonate concentration was positively correlated with the positive DCAD effect on DMI (Tucker et al., 1988a; West et al., 1991). The absence of a DCAD effect for DMI and serum bicarbonate, coupled with the increase in urinary excretion of bicarbonate (Table 7) for HD suggests that the cow's buffering needs were satisfied by the DCAD of $45 \mathrm{mEq} / 100 \mathrm{~g}$ of DM. Blood urea $\mathrm{N}$ concentrations were higher $(P<0.001)$ for $\mathrm{LD}(17.0$ $\mathrm{mg} / \mathrm{dL})$ compared with HD (14.5 mg/dL). Cai and Zimmerman (1995) reported increased plasma urea $\mathrm{N}$ and decreased plasma ammonia as DCAD increased, although there was no effect of DCAD on total plasma N (urea + ammonia + allantoin). Phillip (1983) reported reduced ruminal ammonia concentrations in lambs fed supplemental $\mathrm{NaHCO}_{3}$. The author proposed that the addition of $\mathrm{NaHCO}_{3}$ either enhanced microbial utilization of ruminal ammonia or raised ruminal $\mathrm{pH}$ such that absorption of ruminal ammonia increased. The lower BUN observed for the HD suggests that greater absorption of ruminal ammonia may not be occurring.

Table 6. Serum mineral and metabolite concentrations for cows fed diets containing a DCAD of 41 or $58 \mathrm{mEq}(\mathrm{Na}+\mathrm{K}-\mathrm{Cl}) / 100 \mathrm{~g}$ of DM and $\mathrm{K}: \mathrm{Na}$ ratio of $2: 1,3: 1$, or $4: 1$

\begin{tabular}{|c|c|c|c|c|c|c|c|c|c|c|}
\hline \multirow[b]{2}{*}{ Item } & \multicolumn{6}{|c|}{$\mathrm{DCAD}$ and $\mathrm{K}: \mathrm{Na}$ ratio } & \multirow[b]{2}{*}{ SEM } & \multicolumn{3}{|c|}{$P$} \\
\hline & $2: 1$ & $3: 1$ & $4: 1$ & $2: 1$ & $3: 1$ & $4: 1$ & & DCAD & Ratio & $\mathrm{DCAD} \times$ Ratio \\
\hline $\mathrm{Ca}, \mathrm{mg} / \mathrm{dL}$ & 10.19 & 10.03 & 9.93 & 9.92 & 9.87 & 10.07 & 0.12 & $\mathrm{NS}^{1}$ & NS & NS \\
\hline $\mathrm{Mg}, \mathrm{mg} / \mathrm{dL}$ & 2.51 & 2.42 & 2.59 & 2.37 & 2.38 & 2.70 & 0.08 & NS & $\mathrm{L}^{2 *}$ & NS \\
\hline $\mathrm{Na}, \mathrm{mmol} / \mathrm{L}$ & 144.8 & 144.6 & 144.6 & 143.9 & 144.4 & 144.7 & 0.4 & NS & NS & NS \\
\hline $\mathrm{K}, \mathrm{mmol} / \mathrm{L}$ & 4.67 & 4.83 & 4.78 & 4.58 & 4.64 & 4.82 & 0.09 & NS & $\mathrm{L} \dagger$ & NS \\
\hline Bicarbonate, $\mathrm{mmol} / \mathrm{L}$ & 22.1 & 21.9 & 22.8 & 22.9 & 22.5 & 22.8 & 0.5 & NS & NS & NS \\
\hline
\end{tabular}

${ }^{1} \mathrm{NS}=$ Not significant $(P>0.10)$.

${ }^{2} \mathrm{~L}=$ Linear effect.

${ }^{3} \mathrm{Q}=$ Quadratic effect.

$\dagger P<0.10 ; * P<0.05$; *** $P<0.001$. 
Table 7. Urinary excretion of mineral and metabolites for cows fed diets containing a DCAD of 41 or $58 \mathrm{mEq}(\mathrm{Na}+\mathrm{K}-\mathrm{Cl}) / 100 \mathrm{~g}$ of $\mathrm{DM}$ and $\mathrm{K}: \mathrm{Na}$ ratio of $2: 1,3: 1$, or $4: 1$

\begin{tabular}{|c|c|c|c|c|c|c|c|c|c|c|}
\hline \multirow[b]{2}{*}{ Item } & \multicolumn{6}{|c|}{ DCAD and $\mathrm{K}: \mathrm{Na}$ ratio } & \multirow[b]{2}{*}{ SEM } & \multicolumn{3}{|c|}{$P$} \\
\hline & $2: 1$ & $3: 1$ & $4: 1$ & $2: 1$ & $3: 1$ & $4: 1$ & & DCAD & Ratio & $\mathrm{DCAD} \times$ Ratio \\
\hline \multicolumn{11}{|c|}{ Fractional excretion, ${ }^{1} \%$} \\
\hline $\mathrm{Ca}$ & 0.26 & 0.23 & 0.35 & 0.26 & 0.20 & 0.28 & 0.08 & $\mathrm{NS}^{2}$ & NS & NS \\
\hline $\mathrm{Mg}$ & 12.6 & 10.1 & 16.4 & 10.9 & 7.4 & 14.7 & 2.2 & NS & $\mathrm{Q}^{3 *}$ & NS \\
\hline $\mathrm{Na}$ & 1.80 & 1.45 & 1.12 & 2.16 & 1.38 & 1.32 & 0.19 & NS & $\mathrm{L}^{4 * * * *}$ & NS \\
\hline \multicolumn{11}{|c|}{ Urine metabolite/urine creatinine ${ }^{5}$} \\
\hline Urea N & 10.6 & 10.3 & 10.7 & 10.1 & 10.2 & 10.6 & 0.4 & NS & NS & NS \\
\hline Bicarbonate & 2.38 & 2.72 & 2.54 & 3.52 & 3.06 & 3.70 & 0.34 & $* *$ & NS & NS \\
\hline
\end{tabular}

${ }^{1}$ Fractional excretion $=([$ urinary mineral $] /$ [plasma mineral $\left.]\right) \times($ [plasma creatinine] $/$ [urinary creatinine $\left.]\right) \times 100 ;$ Vander, 1991.

${ }^{2} \mathrm{NS}=$ Not significant $(P>0.10)$.

${ }^{3} \mathrm{Q}=$ Quadratic effect.

${ }^{4} \mathrm{~L}=$ Linear effect.

${ }^{5}$ Expressed as (milligrams of urine metabolite/100 mL of urine)/(milligrams of urine creatinine/100 mL of urine).

$\dagger P<0.10 ; * P<0.05 ; * * P<0.01 ; * * * P<0.001$.

Reduced BUN coupled with decreased rumen ammonia noted in previous research (Phillip, 1983) suggests the possibility for enhanced microbial utilization of ruminal ammonia for protein synthesis.

As the $\mathrm{K}: \mathrm{Na}$ ratio increased, serum $\mathrm{Mg}$ increased linearly $(P<0.05)$. This is in contrast with previous research (Ram et al., 1998; Jittakhot et al., 2004) in which greater dietary $\mathrm{K}$ concentration reduced $\mathrm{Mg}$ absorption. Leonhard-Marek and Martens (1996) reported that in isolated ruminal epithelium, the relationship between ruminal $\mathrm{K}$ concentration and the mucosal to serosal $\mathrm{Mg}$ flux reach a plateau at high ruminal $\mathrm{K}$ concentrations, resulting in decreased suppression of $\mathrm{Mg}$ absorption. Jittakhot et al. (2004) reported that the plateau of mucosal to serosal $\mathrm{Mg}$ flux did not decrease suppression of $\mathrm{Mg}$ absorption at high $\mathrm{K}$ levels in nonpregnant, dry cows. Dietary $\mathrm{K}$ concentration in that study was considerably lower than that in the present study. Ruminal K concentration for the $\mathrm{KNa} 4$ ratio may have been sufficiently high to reach the plateau and the suppression in $\mathrm{Mg}$ absorption was alleviated. Serum $\mathrm{Mg}$ increased to $2.65 \mathrm{mg} / \mathrm{dL}$ for $\mathrm{KNa} 4$ from 2.44 and $2.40 \mathrm{mg} / \mathrm{dL}$ for $\mathrm{KNa} 2$ and $\mathrm{KNa} 3$, respectively.

A significant quadratic $\mathrm{K}: \mathrm{Na}$ ratio effect was noted for BUN $(P<0.10$; Table 6$)$. The BUN concentration for $\mathrm{KNa} 3(14.9 \mathrm{mg} / \mathrm{dL})$ was lower than that observed for KNa2 (15.7 mg/dL) and KNa4 (16.7 mg/dL). Greater BUN for $\mathrm{KNa} 4$ may be explained by the relationship between dietary $\mathrm{K}$ and intracellular AA concentration. Greater free muscle AA concentrations in rats (Arnauld and Lachance, 1980) and chicks (Austic and Calvert, 1981) were reported when dietary $K$ was elevated. Greater dietary $\mathrm{K}$ in $\mathrm{KNa} 4$ may have led to increased availability of free AA. If available in excess, these AA may be catabolized as an energy source, resulting in greater BUN. A linear increase $(P<0.05)$ for serum $\mathrm{K}$ concentration with increasing $\mathrm{K}: \mathrm{Na}$ ratio was also observed, probably a result of increasing dietary $\mathrm{K}$ concentration (Table 2).

There was a trend for an interaction of $\mathrm{DCAD} \times \mathrm{K}: \mathrm{Na}$ ratio $(P<0.10)$ for fractional excretion of $\mathrm{K}$ (Table 7$)$. The increase in $\mathrm{K}$ excretion between $\mathrm{KNa} 2$ and $\mathrm{KNa} 3$ was similar between DCAD concentrations (17.4 and $16.1 \%$ increase for $\mathrm{LD}$ and $\mathrm{HD}$, respectively), but the increase in $\mathrm{K}$ excretion between $\mathrm{KNa} 3$ and $\mathrm{KNa} 4$ was considerably larger for HD (26.9\%) compared with LD $(10.5 \%)$. This is consistent with the increase in dietary $\mathrm{K}$ for these treatments (Table 2). Fractional excretion of Na declined linearly $(P<0.001)$ as K:Na ratio increased because dietary $\mathrm{Na}$ concentration decreased with increasing $\mathrm{K}: \mathrm{Na}$ ratio (Table 2), resulting in decreased $\mathrm{Na}$ fractional excretion.

\section{CONCLUSIONS}

The quadratic response for MY and ECM by K:Na ratio suggests that increasing DCAD primarily with $\mathrm{Na}$ or $\mathrm{K}$ affected milk yield, with the lowest ECM produced at a $3: 1 \mathrm{~K}: \mathrm{Na}$ ratio $(27.1 \mathrm{~kg} / \mathrm{d})$ compared with ratios of $2: 1(29.3 \mathrm{~kg} / \mathrm{d})$ and $4: 1(28.7 \mathrm{~kg} / \mathrm{d})$. The absence of a DCAD effect for DMI, MY, ECM, and blood bicarbonate along with increased fractional excretion of bicarbonate with greater DCAD concentration suggests that blood buffering was adequate at either DCAD used in the present study. The absence of a $\mathrm{DCAD} \times \mathrm{K}: \mathrm{Na}$ ratio interaction for DMI, MY, and ECM also suggests that 
production is not improved when DCAD is elevated outside of the optimum range of 25 to $50 \mathrm{mEq}(\mathrm{Na}+\mathrm{K}$ $-\mathrm{Cl}) / 100 \mathrm{~g}$ of DM even with altered K:Na ratio. Lower BUN in cows fed a high DCAD concentration suggests the possibility of enhanced microbial ammonia utilization resulting in greater microbial $\mathrm{CP}$. The mechanism behind these changes in protein metabolism is unclear and warrants further investigation. By elucidating these effects, the efficiency with which protein is fed can be improved.

\section{REFERENCES}

Arnauld, J., and P. A. Lachance. 1980. Basic amino acid accumulation in potassium-depleted rat muscle. J. Nutr. 110:2480-2489.

AOAC. 1990. Official Methods of Analysis. 15th ed. Association of Official Analytical Chemists, Arlington, VA.

Austic, R. E., and C. C. Calvert. 1981. Nutritional interrelationships of electrolytes and amino acids. Fed. Proc. 40:63-67.

Bitman, J., A. Lefcourt, D. L. Wood, and B. Stroud. 1982. Circadian and ultradian temperature rhythms in lactating dairy cows. J. Dairy Sci. 65(Suppl. 1):191. (Abstr.)

Block, E. 1984. Manipulating dietary anions and cations for prepartum cows to reduce incidence of milk fever. J. Dairy Sci. 67:2939-2948.

Block, E. 1994. Manipulation of dietary cation-anion difference on nutritionally related production diseases, productivity, and metabolic responses of dairy cows. J. Dairy Sci. 77:1437-1450.

Cai, Y., and D. R. Zimmerman. 1995. Relationship of plasma urea nitrogen and urea-cycle amino acid concentrations in swine to dietary electrolyte balance and water intake. Nutr. Res. 15:1517-1524.

Cotlove, E. H., H. V. Trantham, and R. L. Bowman. 1958. An instrument and method for automatic, rapid, accurate, and sensitive titration of chloride in biological samples. J. Lab. Clin. Med. 51:461-465.

Erdman, R. A., R. W. Hemken, and L. S. Bull. 1980. Effects of dietary calcium and sodium on potassium requirements for lactating dairy cows. J. Dairy Sci. 63:538-544.

Hu, W., and M. R. Murphy. 2004. Dietary cation-anion difference effects on performance and acid-base status of lactating dairy cows: A meta-analysis. J. Dairy Sci. 87:2222-2229.

Igono, M. O., H. D. Johnson, B. J. Steevens, G. F. Krause, and M. D. Shanklin. 1987. Physiological, productive, and economic benefits of shade, spray, and fan system versus shade for Holstein cows during summer heat. J. Dairy Sci. 70:1069-1079.

Igono, M. O., B. J. Steevens, M. D. Shanklin, and H. D. Johnson. 1985. Spray cooling effects on milk production, milk, and rectal temperatures of cows during a moderate temperate summer season. J. Dairy Sci. 68:979-985.

Jittakhot, S., J. T. Schonewille, H. Wouterse, C. Yuangklang, and A. C. Beynen. 2004. Apparent magnesium absorption in dry cows fed at 3 levels of potassium and 2 levels of magnesium intake. J. Dairy Sci. 87:379-385.

Johnson, H. D. 1987. Bioclimates and Livestock. Pages 3-16 in World Animal Science Series. H. D. Johnson, ed. Elsevier Science Publ. Co., Amsterdam, the Netherlands.

Leonhard-Marek, S., and H. Martens. 1996. Effects of potassium on magnesium transport across rumen epithelium. Am. J. Physiol. 271:G1034-G1038.

NOAA. 1976. Livestock hot weather stress. Regional Operations Manual Letter C-31-76. National Oceanic and Atmospheric Administration. US Govt. Printing Office, Washington, DC.
National Research Council. 2001. Nutrient Requirements of Dairy Cattle. 7th rev. ed. Natl. Acad. Sci., Washington, DC.

O'Connor, A. M., D. K. Beede, and C. J. Wilcox. 1988. Lactational responses to dietary magnesium, potassium, and sodium during winter in Florida. J. Dairy Sci. 71:971-981.

Oetzel, G. R., J. D. Olson, C. R. Curtis, and M. J. Fettman. 1988. Ammonium chloride and ammonium sulfate for prevention of parturient paresis in dairy cows. J. Dairy Sci. 71:3302-3309.

Patience, J. F., and R. K. Chaplin. 1997. The relationship among dietary undetermined anion, acid-base balance, and nutrient metabolism in swine. J. Anim. Sci. 75:2445-2452.

Phillip, L. E. 1983. Effect of sodium bicarbonate on nitrogen utilization and feed intake by lambs. Can. J. Anim. Sci. 63:613-621.

Ram, L., J. T. Schonewille, H. Martens, A. T. Van't Klooster, and A. C. Beynen. 1998. Magnesium absorption by wethers fed potassium bicarbonate in combination with different dietary magnesium concentrations. J. Dairy Sci. 81:2485-2492.

Ross, J. G., J. W. Spears, and J. D. Garlich. 1994. Dietary electrolyte balance effects on performance and metabolic characteristics in finishing steers. J. Anim. Sci. 72:1600-1607.

Sanchez, W. K., and D. K. Beede. 1994. Interactions of sodium, potassium, and chloride on lactation, acid-base status, and mineral concentrations. J. Dairy Sci. 77:1661-1675.

Sanchez, W. K., and D. K. Beede. 1996. Is there an optimal cationanion difference for lactation diets? Anim. Feed Sci. Technol. 59:3-12.

Sanchez, W. K., D. K. Beede, and J. A. Cornell. 1997. Dietary mixtures of sodium bicarbonate, sodium chloride, and potassium chloride: Effects on lactational performance, acid-base status, and mineral metabolism of Holstein cows. J. Dairy Sci. 80:1207-1216.

Sanchez, W. K., D. K. Beede, and M. A. Delorenzo. 1994. Macromineral element interrelationships and lactational performance: Empirical models from a large data set. J. Dairy Sci. 77:3096-3110.

SAS Institute. 1999. SAS User's Guide: Statistics. Version 8 ed. SAS Institute Inc., Cary, NC.

Schneider, P. L., D. K. Beede, C. J. Wilcox, and R. J. Collier. 1984. Influence of dietary sodium and potassium bicarbonate on total potassium on heat-stressed lactating dairy cows. J. Dairy Sci. 67:2546-2553.

Tucker, W. B., G. A. Harrison, and R. W. Hemken. 1988a. Influence of dietary cation-anion balance on milk, blood, urine, and rumen fluid in lactating dairy cattle. J. Dairy Sci. 71:346-354.

Tucker, W. B., J. F. Hogue, D. E. Waterman, T. S. Swenson, Z. Xin, R. W. Hemken, J. A. Jackson, G. D. Adams, and L. J. Spicer. 1991. Role of sulfur and chloride in the dietary cation-anion balance equation for lactating dairy-cattle. J. Anim. Sci. 69:1205-1213.

Tucker, W. B., Z. Xin, and R. W. Hemken. 1988b. Influence of dietary calcium chloride on adaptive changes in acid-base status and mineral metabolism in lactating dairy cows fed a diet high in sodium bicarbonate. J. Dairy Sci. 71:1587-1597.

Tyrrell, H. F., and J. T. Reid. 1965. Prediction of the energy value of cow's milk. J. Dairy Sci. 48:1215-1223.

Van Soest, P. J., J. B. Robertson, and B. A. Lewis. 1991. Methods for dietary fiber, neutral detergent fiber, and nonstarch polysaccharides in relation to animal nutrition. J. Dairy Sci. 74:35833597.

Vander, A. J. 1991. Renal Physiology. 4th ed. McGraw-Hill Inc., New York, NY.

West, J. W., K. D. Haydon, B. G. Mullinix, and T. G. Sandifer. 1992. Dietary cation-anion balance and cation source effects on production and acid-base status of heat-stressed cows. J. Dairy Sci. 75:2776-2786.

West, J. W., B. G. Mullinix, and T. G. Sandifer. 1991. Changing dietary electrolyte balance for dairy cows in cool and hot environments. J. Dairy Sci. 74:1662-1674. 